\title{
Genetic structure of Tunisian natural carob tree (Ceratonia siliqua L.) populations inferred from RAPD markers
}

\author{
Makrem AfIF $^{1}$, Chokri Messaoud ${ }^{1}$, Abdennacer Boulila ${ }^{1}$, Hnia CHOGRANi $^{1}$, Afef BeJAOUI $^{1}$, \\ Mohamed Nejib REJEB ${ }^{2}$, Mohamed BousSAID ${ }^{1 *}$
${ }^{1}$ National Institute of Applied Sciences and Technology (INSAT) Department of Biology Laboratory of Plant Biotechnology Centre Urbain Nord, BP 676, 1080 Tunis Cedex, Tunisia \\ ${ }^{2}$ National Institute of Research in Agricultural Engineering, Water and Forests, BP 10, Ariana- 2080 Tunisia
}

(Received 29 October 2007; accepted 1 July 2008)

Keywords:

genetic diversity /

RAPD /

Ceratonia siliqua /

natural populations /

bioclimate /

conservation

\begin{abstract}
- Seven RAPD markers were used to assess the genetic diversity and structure of ten Tunisian natural Ceratonia siliqua L. populations from different geographic and bioclimatic zones.

- The species maintain a high diversity within population as estimated by the percentage of polymorphic loci and Shannon's index $\left(P \%=76.31, \overline{\mathrm{H}}_{\text {pop }}^{\prime}=0.569\right)$. The range of variation between populations was large. Populations from the upper semi-arid bioclimates, with more continuous distribution area showed the highest level of variation.

- A high genetic differentiation among populations $\left(\Phi_{\mathrm{ST}}=0.250\right.$ and $\left.\overline{\mathrm{G}}_{\mathrm{ST}}=0.347\right)$, as a result of population isolation was revealed. Nevertheless, the genetic structure is in accordance with bioclimate indicating that ecological factors also should influence differentiation. Populations from the sub-humid, upper semi-arid and mean semi-arid zones clustered together and were distinct from those of the lower semi-arid ones.

- Conservation strategy should be made according to the level of polymorphism within population and bioclimate.
\end{abstract}

Résumé - Structure génétique des populations naturelles du caroubier (Ceratonia siliqua $\mathbf{L}$.) en Tunisie estimée par les marqueurs RAPD.

diversité génétique /

RAPD /

Ceratonia siliqua / populations naturelles /

bioclimat /

conservation
- Sept marqueurs RAPD ont été utilisés pour analyser la diversité et la structure génétique de dix populations tunisiennes de caroubier (Ceratonia siliqua L.) prospectées dans différentes zones géographiques et bioclimatiques.

- L'espèce maintient une diversité génétique intra population importante $\left(P \%=76.31 ; \overline{\mathrm{H}}_{\mathrm{pop}}^{\prime}=0.569\right)$ et les niveaux de variation diffèrent selon les populations. Celles du subhumide et du semi-aride supérieur, à aire de distribution plus continue, ont montré la variation la plus importante.

- Une forte différenciation $\left(\Phi_{\mathrm{ST}}=0.250\right.$ et $\left.\overline{\mathrm{G}}_{\mathrm{ST}}^{\prime}=0.347\right)$ entre les populations, due à leur fragmentation récente, est observée. Toutefois, cette différenciation concorde avec le bioclimat des sites témoignant l'influence des facteurs écologiques dans cette différenciation. Les populations du subhumide, du semi-aride supérieur et du semi-aride moyen constituent un groupe distinct de celui représenté par les populations du semi-aride inférieur.

- La conservation des populations doit tenir compte de leur niveau de diversité génétique intra population et du bioclimat.

\section{INTRODUCTION}

Ceratonia siliqua L. (Caesalpinioideae) is a diploid forest (or semi forest) tree $(2 n=2 x=24)$ native from the Mediterranean basin (Battle, 1997; Mitrakos, 1968; Talhouk et al.,

*Corresponding author: mohamed.boussaid@insat.rnu.tn
2005). It has been cultivated for a long time in many countries (i.e. Spain, Italy, Turkey, Greece, Morocco, Tunisia, USA, Australia, etc), for human and animal consumption (Albanell et al., 1996; Calixto and Canellas, 1982), and for restoration of degraded arid areas (Battle and Tous, 1997; Correia and Martin-Louçào 2005). At present, the demand for this plant (mainly for seed products) is increasing for pharmaceutical 
(Khair et al., 2001) dietetic, food and cosmetic uses (Albanell et al., 1991; 1996; Corsi et al., 2002; Roukas, 1994). However, most of the material used by these industries comes from wild populations which are more and more destroyed, and replaced with more profitable species (i.e. Olea europea, Vitis vinifera, Ficus carica). The number of carob orchards, mainly in North Africa, is small, they are abandoned and pods are frequently left on trees. In most Mediterranean countries (except Spain) a lack of selected cultivars was observed (Battle and Tous, 1997).

In Tunisia, Carob populations grew in uninterrupted expanses in the Northern (Mogods) and Central (Tunisian Dorsal) areas, and in the Northern coast (Cap Bon) under a rainfall ranging between 350 and $800 \mathrm{~mm} / \mathrm{year}$ (Rejeb, 1989). Populations are associated with Pistacia lentiscus and/or Olea europea and grow on calcareous, sandy or low-clayey soils at altitudes varying from 300 to $970 \mathrm{~m}$. Forest clearing for the cultivation of olive trees, cereals and vine, and for charcoal production have led to an extensive carob habitat destruction (mainly in the coast region). The species, at present, is mainly represented by fragmented populations with scattered individuals (Afif et al., 2006; Boussaïd et al., 1998; Le Houerou and Le Floc'h, 1995). Populations, except for those preserved within forests of Zaghouan and Bargou Jbel Mountains, are facing high degradation and isolation with an unknown impact on their genetic diversity and structure. The capacity of populations maintenance is dependent on their adaptive potential to environmental changes, which determined by their genetic diversity level.

Assessing the genetic diversity (via morphological, isozymic and molecular markers) within and among populations, according to their ecological distribution, would be required to ensure the in situ maintenance of populations and to draw up conservation and improvement strategies.

Studies addressing genetic diversity and differentiation among natural carob populations in the Mediterranean countries are very limited. Work using isozyme markers reported that Tunisian carob populations maintain a high variation within populations, and their genetic structure is concordant with bioclimate (Afif et al., 2006). Based on RAPDs, Talhouk et al. (2005) showed that Lebanese semi-natural carob populations exhibit significant genetic variation within and among populations. The populations are not clustered according to their geographic proximity. Analyses, using isozymes, performed on carob cultivars from different origins have shown low polymorphism between accessions indicating that selection has been performed from a narrow genetic base (Tous et al., 1992).

This study aimed to assess the genetic variation in Tunisian carob populations using random amplified polymorphic DNA (RAPD) to improve current understanding of the species genetic diversity and population structure. This work is an extension of that initiated on Tunisian carob population genetic structure based on isozymes for the same populations (Afif et al., 2006).

RAPD markers are an appreciable tool for population genetic studies (Besse et al., 2004; Fischer et al., 2000; Mariette et al., 2007; Sudupak et al., 2002; Williams et al., 1990)

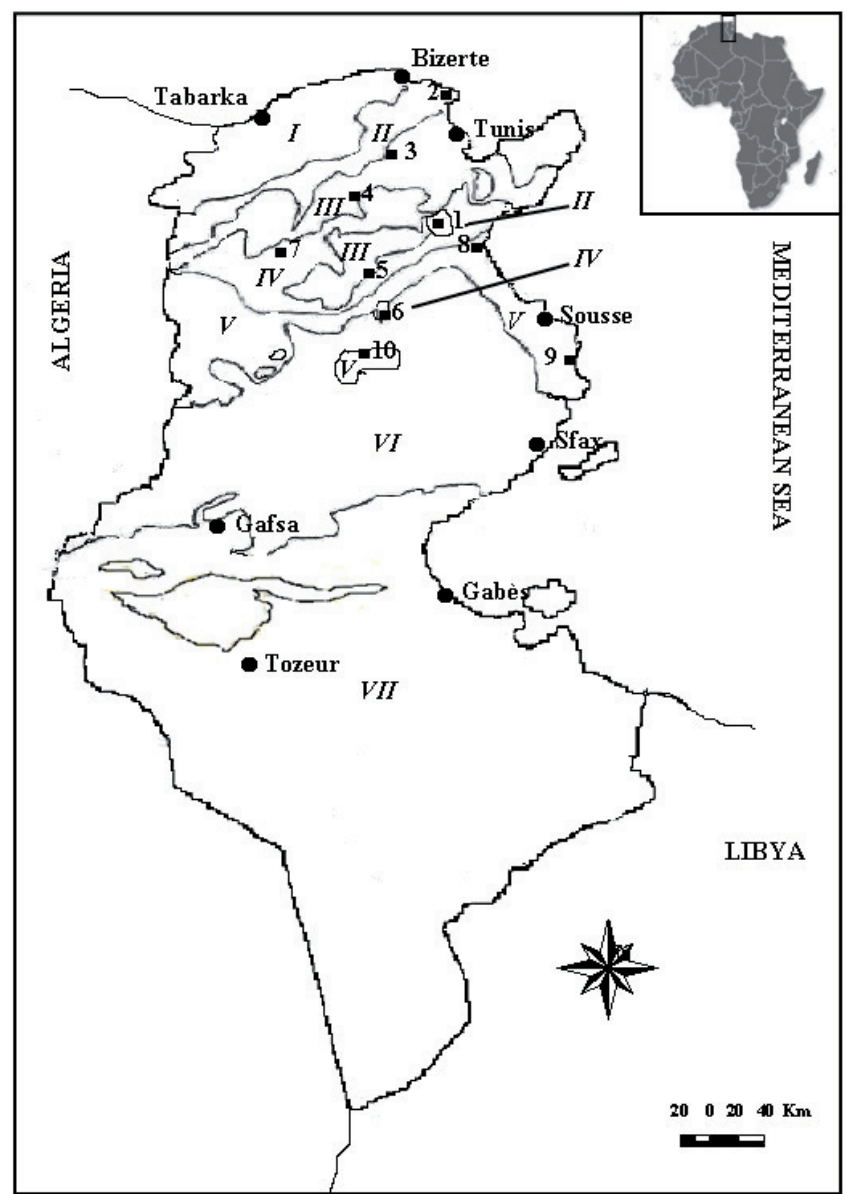

Figure 1. Map of Tunisia: Geographical distribution of the 10; Ceratonia siliqua populations analysed. $\mathbf{\square} 1,2, \ldots, 10$ : populations I. ...VII: Bioclimatic zones; I: Lower humid, II: Sub-humid, III: Upper semi-arid, $I V$ : Mean semi-arid, $V$ : Lower semi-arid, $V I$ : Lower arid, VII: Saharian. ffl Greatest cites.

particularly in woody plants (Lee et al., 2002). These markers can reveal a high number of loci, providing a more representative sample of the genome than is possible with isozymes. They are able of detecting variation in non-coding regions of the genome. However, RAPDs, as isozymes, have some limitations. The most one is their dominant expression that can bias the genetic diversity and differentiation among populations (Allnutt et al., 2003; Nybom and Bartish 2000; Wu et al., 1999).

\section{MATERIAL AND METHODS}

\subsection{Analysed populations}

Ten populations from different areas extending from the North to the Center of the country were assessed (Fig. 1 and Tab. I). They belong to sub-humid (populations 1 and 2), upper semi-arid (populations 3, 4 and 5), mean semi-arid (populations 6 and 7) and lower semi-arid (populations 8,9 and 10) bioclimates according to Emberger's (1966) pluviothermic coefficient $\left(\mathrm{Q}_{2}\right)$. The geographic 
Table I. Main ecological characteristics for the 10 Tunisian Ceratonia siliqua populations analysed.

\begin{tabular}{|c|c|c|c|c|c|c|c|}
\hline Population & Code & $\begin{array}{l}\text { Altitude } \\
\text { (m) }\end{array}$ & Latitude & Longitude & $\begin{array}{c}\text { Rainfall } \\
\text { (mm/year) }\end{array}$ & ${ }^{*} \mathrm{Q}_{2}$ coefficient & $\begin{array}{l}\text { Bioclimatic zone }^{b} \\
\text { (ecological group) }\end{array}$ \\
\hline Zaghouan Jb. $\mathrm{Mt}^{a}$ & 1 & 970 & $36^{\circ} 23^{\prime} \mathrm{N}$ & $10^{\circ} 08^{\prime} \mathrm{E}$ & $500-600$ & 65.47 & \multirow{2}{*}{ Sub-humid } \\
\hline Ghar El Melh & 2 & 420 & $37^{\circ} 20^{\prime} \mathrm{N}$ & $10^{\circ} 14^{\prime} \mathrm{E}$ & $500-600$ & 88.70 & \\
\hline Lansarine $\mathrm{Jb}$. Mt & 3 & 480 & $37^{\circ} 05^{\prime} \mathrm{N}$ & $09^{\circ} 44^{\prime} \mathrm{E}$ & $500-600$ & 52.39 & \multirow{3}{*}{ Upper semi-arid } \\
\hline El Morra Jb. Mt & 4 & 580 & $36^{\circ} 35^{\prime} \mathrm{N}$ & $09^{\circ} 37^{\prime} \mathrm{E}$ & $500-600$ & 62.64 & \\
\hline Bargou Jb. Mt & 5 & 865 & $36^{\circ} 05^{\prime} \mathrm{N}$ & $09^{\circ} 30^{\prime} \mathrm{E}$ & $400-500$ & 45.72 & \\
\hline Ksar El Lamsa & 6 & 610 & $35^{\circ} 58^{\prime} \mathrm{N}$ & $09^{\circ} 37^{\prime} \mathrm{E}$ & $400-500$ & 42.68 & \multirow{2}{*}{ Mean semi-arid } \\
\hline Aïn Toungua & 7 & 475 & $36^{\circ} 34^{\prime} \mathrm{N}$ & $09^{\circ} 34^{\prime} \mathrm{E}$ & $400-500$ & 40.35 & \\
\hline Jradou & 8 & 565 & $36^{\circ} 17^{\prime} \mathrm{N}$ & $10^{\circ} 19^{\prime} \mathrm{E}$ & $300-400$ & 37.52 & \multirow{3}{*}{ Lower semi-arid } \\
\hline Khnis & 9 & 300 & $35^{\circ} 45^{\prime} \mathrm{N}$ & $10^{\circ} 49^{\prime} \mathrm{E}$ & $350-500$ & 36.75 & \\
\hline Oueslet Jb. Mt & 10 & 887 & $35^{\circ} 53^{\prime} \mathrm{N}$ & $09^{\circ} 44^{\prime} \mathrm{E}$ & $400-500$ & 37.46 & \\
\hline
\end{tabular}

${ }^{\mathrm{a}} \mathrm{Jb} . \mathrm{Mt}=$ Jbel Mountain.

b Bioclimatic zones were defined according to Emberger's (1966) $\mathrm{Q}_{2}$ pluviothermic coefficient $\mathrm{Q}_{2}=2000 P / M^{2}-m^{2}$ where $P$ is the average of annual rainfall $(\mathrm{mm}), M$ is the mean of maximal temperature (K: Kelvin) for the warmest month (July) and $m$ is the average of minimal temperature (K) for the coldest month (February).

* $\mathrm{Q}_{2}$ was calculated for each site using $P, M$ and $m$ average values for the period 1953-2003 from data provided by the Tunisian National Institute of Meteorology.

distribution of populations generally matches that of their bioclimatic zones. Altitudes of sites ranged from 300 to $970 \mathrm{~m}$. The average annual rainfall varied from 300 to $600 \mathrm{~mm}$. Populations, except for those from Zaghouan (1), El Morra (4) and Bargou (5) Jbel Mountains and Ksar Lamsa (6) are represented by scattered individuals.

Ten individuals in each population were collected with a minimum of $200 \mathrm{~m}$ between trees (the number of samples is limited because of the small size of most populations). From each individual, branches with young leaves were taken, placed on ice in plastic bags and transported to the laboratory for molecular analyses.

\subsection{DNA extraction}

DNA was isolated according to a modified CTAB method (Lodhi et al., 1994) by the use of $\mathrm{NaCl}$ (5 M) to remove polysaccharides and PVP to eliminate polyphenols during DNA purification. Five hundred milligrams of leaves from each plant were grounded to fine powder in liquid nitrogen and mixed with $2 \mathrm{ml}$ of preheated CTAB extraction buffer added a 1\% PVP (40000). Extraction was performed using equal volume of chloroform-isoamyl alcohol (24:1). Cold ethanol 95\% was employed to precipitate the DNA which was washed with $10 \mathrm{mM}$ ammonium acetate in $76 \%$ ethanol, and dried. The DNA pellet was re-suspended in TE buffer (10 mM Tris-HCl, $0.1 \mathrm{mM}$ EDTA). After total DNA dissolution, the RNA was eliminated by adding $2 \mu \mathrm{L}$ of Rnase-Dnase free solution $(10 \mu \mathrm{g} / \mathrm{mL})$. DNA quantity was estimated spectrophotometrically by measuring absorbance at $260 \mathrm{~nm}$.

\subsection{Random amplification and sampling primers}

Reactions were standardized and all PCR reactions were run on the same thermal cycler (Mark Maximum-Gene). For every $25 \mu \mathrm{L}$ of volume reaction, $50 \mathrm{ng}$ of DNA, $2.5 \mu \mathrm{L}$ of $10 \mathrm{X}$ Taq polymerase buffer, $40 \mathrm{pM}$ of primer, $2.5 \mathrm{mM}$ of $\mathrm{MgCl} 2,200 \mu \mathrm{M}$ of dNTP and 1.5
$\mathrm{U}$ of Taq polymerase were included. Each reaction was overlaid with an equal volume of mineral oil.

The PCR program was set as follow: An initial denaturation step of $94{ }^{\circ} \mathrm{C}$ for $2 \mathrm{~min}$, followed by 45 cycles of $30 \mathrm{~s}$ at $94{ }^{\circ} \mathrm{C}, 1 \mathrm{~min}$ at $36{ }^{\circ} \mathrm{C}$ (annealing step), and $2 \mathrm{~min}$ at $72{ }^{\circ} \mathrm{C}$ (elongation step). An additional $10 \mathrm{~min}$ period for elongation at $72{ }^{\circ} \mathrm{C}$ followed this cycle.

Amplification products were separated by electrophoresis in $1.5 \%$ agarose gels made with $1 \mathrm{X}$ TAE buffer $(\mathrm{pH} 8)$, stained with ethidium bromide and visualized under UV light. As a size marker, a $200 \mathrm{~Pb}$ DNA Ladder (Promega) was run in each gel.

Seven out of 20-tested RAPD primers (from Operon Technologies) were selected according to consistency, reproducibility and polymorphism level of electrophoretic bands to amplify DNAs. Primers used are: OPJ04 (5'CCGAACACGG3'), OPJ06 (5'TCGTTCCGCA3'), OPJ08 (5'CATACCGTGG3'), OPJ12 (5'GTCCCGTGGT3'), OPJ13 (5'CCACACTACC3'), OPJ14 (5'CACCCGGATG3') and OPJ20 (5'AAGCGGCCTC3') (for examples, see addendum online only).

\subsection{Data analysis}

RAPD markers were scored as presence (1) or absence $(0)$ on a band. A data matrix based on all the observed bands was constructed. In each population and ecological group (populations from the same bioclimate), the genetic diversity was estimated by the percentage of polymorphic bands $(P \%)$, which was calculated by dividing the number of polymorphic bands at population (or ecological group) and species levels by the total number of bands surveyed.

A binary matrix of RAPD's phenotypes was used to calculate frequencies of markers within population and species. The Shannon's index for each RAPD locus was calculated for each population as: $\mathrm{H}_{j}^{\prime}=-\Sigma p_{\mathrm{i}} \log _{2} p_{\mathrm{i}}$; where $p_{\mathrm{i}}$ is the frequency of the presence or absence of a RAPD band in a population. The average diversity over all populations was calculated for each locus as: $\mathrm{H}_{p o p}^{\prime}=-1 / n \Sigma \mathrm{H}_{j}^{\prime}$; 
where $n$ is the number of populations. The species diversity was estimated for each locus as: $\mathrm{H}_{s p}^{\prime}=-\sum p_{\mathrm{s}} \log _{2} p_{\mathrm{s}}$; where $p_{\mathrm{s}}$ is the frequency of presence or absence of the RAPD in the whole sample. To estimate the level of polymorphism for each primer, each calculated index $\left(\mathrm{H}_{\mathrm{j}}^{\prime}, \mathrm{H}_{\mathrm{pop}}^{\prime}\right.$ and $\left.\mathrm{H}_{\mathrm{sp}}^{\prime}\right)$ for each locus was averaged across primer. We partitioned the species diversity $\left(\mathrm{H}_{\mathrm{sp}}^{\prime}\right)$ into within and among population components, thus for each locus, the component of diversity within populations is $\mathrm{H}_{\mathrm{pop}}^{\prime} / \mathrm{H}_{\mathrm{sp}}^{\prime}$ and the component between populations is $\mathrm{G}_{\mathrm{ST}}^{\prime}\left(\mathrm{G}_{\mathrm{ST}}^{\prime}=\left(\mathrm{H}_{\mathrm{sp}}^{\prime}-\mathrm{H}_{\mathrm{pop}}^{\prime}\right) / \mathrm{H}_{\mathrm{sp}}^{\prime}\right)$. For all loci and for each population we have calculated the average genetic diversity index $\left(\overline{\mathrm{H}}_{\mathrm{j}}^{\prime}\right)$, thus for all loci, we have determined $\overline{\mathrm{H}}_{\mathrm{pop}}^{\prime}, \overline{\mathrm{H}}_{\mathrm{sp}}^{\prime}, \overline{\mathrm{H}}_{\mathrm{pop}}^{\prime} / \overline{\mathrm{H}}_{\mathrm{sp}}^{\prime}$ and $\overline{\mathrm{G}}_{\mathrm{ST}}^{\prime}$. The same Shannon indices were calculated according the ecological groups $\left(\overline{\mathrm{H}}_{\mathrm{jg}}^{\prime}, \overline{\mathrm{H}}_{\text {grp }}^{\prime}, \overline{\mathrm{H}}_{\text {grp }}^{\prime} / \overline{\mathrm{SH}}_{\mathrm{sp}}^{\prime}\right.$ and $\left.\overline{\mathrm{G}}_{\mathrm{STg}}^{\prime}\right)$.

The relationship among RAPD phenotypes also was visualized by a principal coordinate analysis (PCO) using the program MVSP version 3.1 (Kovach, 1999) and by a neighbour-joining tree (Saitou and Nei, 1987) constructed with MEGA program version 2.0 (Kumar et al., 2001), based on Jaccard's (GS) similarity coefficients (see addendum online only). The genetic distances between individuals were calculated as GD = 1 - GS (Christoph et al., 2005; Gower and Legendre, 1986).

An analysis of molecular variance using the program WINAMOVA 1.55 (Excoffier et al., 1992; Stewart and Excoffier, 1996) was performed on the matrix of genetic distances for the estimation of the distribution of genetic variability within and among populations and ecological groups. The program also extracts analogs of F-statistics (so-called $\Phi$-statistics: $\Phi_{\mathrm{ST}}$ (differentiation among populations), $\Phi_{\mathrm{CT}}$ (differentiation among ecological groups) and $\Phi_{\mathrm{SC}}$ (differentiation among populations within groups)). Homogeneity of molecular variance between pairs of populations was tested using Bartlett tests (Bartlett, 1937). Pairwise genetic distances $\left(\Phi_{\mathrm{ST}}\right)$ among the 10 populations allow the estimation of gene flow as the number of individuals migrating among populations per generation, using Wright's (1951) migrate number $\left(\mathrm{Nm}=1 / 4\left[1 / \Phi_{\mathrm{ST}}-1\right]\right)$. To test the significance of the variance components we used 1000 independent permutations runs.

A Mantel test (Mantel, 1967) was used to determine whether the matrix of genetic distances $\left(\Phi_{\mathrm{ST}}\right)$ was correlated with those of geographic distances, Emberger's pluviothermic coefficients $\left(\mathrm{Q}_{2}\right)$ and altitudes using the TFPGA 1.3 program (Miller, 1997). The significance of the correlation was tested after 999 permutations.

A dendrogram, using the program MEGA version 2.0 (Kumar et al., 2001) based on the matrix of $\Phi_{\mathrm{ST}}$, was constructed to estimate the genetic divergence between populations.

\section{RESULTS}

\subsection{Level of genetic diversity}

The seven selected primers generated a total of 114 bands. The number of bands varied from 14 (OPJ06, OPJ12 and OPJ20) to 20 (OPJ08 and OPJ14) (Tab. II). The amplified products size ranged from 200 to $3000 \mathrm{bp}$. The percentage of polymorphism $(P \%)$ over all populations varied from 70 (OPJ14) to $85.71 \%$ (OPJ20) according to primer, with an average of $76.31 \%$ (Tab. II). For all assessed primers, the highest P\% value $(64.91 \%)$ was observed for population 5 (Bargou Jbel Mountain), whereas the lowest one $(44.74 \%)$ is scored for the population 10 (Oueslet Jbel Mountain). According to ecological groups, the percentage of polymorphism varied from $49.30 \%$ (lower semi-arid) to $61.51 \%$ (upper semi-arid) (Tab. II).

All populations showed a high level of genetic diversity (Tab. III). The Bargou Jbel Mountain population exhibited the highest variation $\left(\overline{\mathrm{H}}_{\mathrm{j}}^{\prime}=0.687\right)$, the lowest variation $\left(\overline{\mathrm{H}}_{\mathrm{j}}^{\prime}=\right.$ 0.458 ) was detected for Jradou population. The average of diversity using all primers at population $\left(\overline{\mathrm{H}}_{\text {pop }}^{\prime}=0.569\right)$ and species $\left(\overline{\mathrm{H}}_{\mathrm{sp}}^{\prime}=0.871\right)$ levels were high. Within ecological groups, the highest Shannon's diversity index $\left(\overline{\mathrm{H}}_{\mathrm{jg}}^{\prime}\right)$ was observed for populations belonging to the upper semi-arid $\left(\overline{\mathrm{H}}_{\mathrm{jg}}^{\prime}=\right.$ $0.763)$; the lowest values $\left(\overline{\mathrm{H}}_{\mathrm{jg}}^{\prime}=0.606\right)$ were recorded for those from the lower semi-arid zone. The most of the variation accrued within population and within ecological group (respectively $\overline{\mathrm{H}}_{\mathrm{pop}}^{\prime} / \overline{\mathrm{H}}_{\mathrm{sp}}^{\prime}=65.3 \%, \overline{\mathrm{H}}_{\mathrm{grp}}^{\prime} / \overline{\mathrm{H}}_{\mathrm{sp}}^{\prime}=80.1 \%$ ). Variations between populations $\left(\overline{\mathrm{G}}_{\mathrm{ST}}^{\prime}=34.7 \%\right)$ and between ecological groups $\left(\overline{\mathrm{G}}_{\mathrm{STg}}^{\prime}=20 \%\right)$ were substantial.

\subsection{Genetic structure}

The average of genetic similarity based on Jaccard's coefficients (GS) was $50.3 \%$. The highest value of GS $(65.4 \%)$ was observed among individuals belonging to population of $\mathrm{Kh}$ nis. The Bargou Jbel Mountain population showed the lowest value $(\mathrm{GS}=52.5 \%)$.

Neighbour-joining analysis produced tow distinct groups (Fig. 2). The first one is constituted by individuals belonging to populations from the sub-humid and the upper semi-arid bioclimates (populations 1, 2, 3, 4 and 5), the second includes individuals from the mean semi-arid and lower semi-arid populations (populations 6, 7, 8, 9 and 10). Several individuals from different populations (in the same bioclimate) were located in a same subcluster.

The plot of the Principal Coordinates Analysis (PCO), according to axes 1 and 2 (described $17.2 \%$ of the total variation) (Plot not shown), revealed a similar population groupings than those showed by the dendrogram (Fig. 3).

All pairs of populations showed significant differentiation $(P<0.001$; after 1000 permutations $)$. The average of $\mathrm{Nm}$ was 1.462 indicating a low gene flow between populations. Zaghouan (1) and Bargou (5) populations were not significantly differentiated $\left(\Phi_{\mathrm{ST}}=0.047 ; P>0.05\right)(\mathrm{Tab}$ IV). The highest $\Phi_{\mathrm{ST}}(0.361)$ and the lowest level of gene flow $(\mathrm{Nm}=0.442)$ were observed between populations of Zaghouan and Oueslet Jbel Mountains (populations 1 and 10) belonging to the subhumid and the lower semi-arid bioclimates respectively. The distance between these populations is $75 \mathrm{Km}$. The lowest differentiation $\left(\Phi_{\mathrm{ST}}=0.040, \mathrm{Nm}=5.862\right)$ was scored among Jradou (8) and Khnis (9) populations, both belonging to the lower semi-arid, and geographically distant by $62 \mathrm{~km}$.

The relationships among $\Phi_{\mathrm{ST}}$ and geographic distance (Mantel's test; $r^{2}=0.091 ; P<0.05$ after 999 permutations) or among $\Phi_{\mathrm{ST}}$ and Emberger's $\mathrm{Q}_{2}$ matrices $\left(r^{2}=0.111\right.$; 
Table II. Percentage of polymorphic loci $(P \%)$ per primer in each population and bioclimatic zone.

\begin{tabular}{|c|c|c|c|c|c|c|c|c|c|}
\hline Bioclimate & $\begin{array}{l}\text { Population } \\
\text { code }\end{array}$ & Primer & OPJ04 & OPJ06 & OPJ08 & OPJ12 & OPJ13 & OPJ14 & OPJ20 \\
\hline \multirow{5}{*}{ Sub-humid } & \multirow{3}{*}{1} & tnb & 17 & 14 & 20 & 14 & 15 & 20 & 14 \\
\hline & & & 47.05 & 64.28 & 80.00 & 50.00 & 66.66 & 60.00 & 42.86 \\
\hline & & & (8) & (9) & (16) & (7) & (10) & (12) & (6) \\
\hline & \multirow[t]{2}{*}{2} & & 58.82 & 50.00 & 65.00 & 42.86 & 53.33 & 55.00 & 64.29 \\
\hline & & & (10) & (7) & (13) & (6) & (8) & (11) & (9) \\
\hline \multirow[t]{3}{*}{ Average } & & & 52.94 & 57.14 & 72.50 & 46.43 & 60.00 & 57.50 & 53.57 \\
\hline & 3 & & 64.70 & 57.14 & 55.00 & 64.29 & 60.00 & 60.00 & 42.86 \\
\hline & & & (11) & (8) & (11) & (9) & (9) & (12) & (6) \\
\hline \multirow{4}{*}{$\begin{array}{c}\text { Upper } \\
\text { Semi-arid }\end{array}$} & 4 & & 53.00 & 64.28 & 70.00 & 71.43 & 73.33 & 60.00 & 42.86 \\
\hline & & & (9) & (9) & (14) & (10) & (11) & (12) & (6) \\
\hline & 5 & & 58.82 & 71.42 & 80.00 & 64.29 & 73.33 & 55.00 & 50.00 \\
\hline & & & (10) & (10) & (16) & (9) & (11) & (11) & (7) \\
\hline \multirow[t]{2}{*}{ Average } & & & 58.82 & 64.28 & 68.33 & 66.66 & 68.88 & 58.33 & 45.23 \\
\hline & 6 & & 70.58 & 50.00 & 65.00 & 64.29 & 73.33 & 50.00 & 57.14 \\
\hline \multirow{3}{*}{$\begin{array}{c}\text { Mean } \\
\text { Semi-arid }\end{array}$} & & & (12) & (7) & (13) & (9) & (11) & (10) & (8) \\
\hline & 7 & & 35.29 & 42.85 & 60.00 & 50.00 & 66.66 & 55.00 & 50.00 \\
\hline & & & (6) & (6) & (12) & (7) & (10) & (11) & (7) \\
\hline \multirow[t]{2}{*}{ Average } & & & 52.94 & 46.42 & 62.50 & 57.14 & 70.00 & 52.50 & 53.57 \\
\hline & 8 & & 47.05 & 35.71 & 55.00 & 28.57 & 73.33 & 40.00 & 57.14 \\
\hline \multirow{5}{*}{$\begin{array}{c}\text { Lower } \\
\text { Semi-arid }\end{array}$} & & & (8) & (5) & (11) & (4) & (11) & (8) & (8) \\
\hline & 9 & & 47.05 & 50.00 & 75.00 & 35.71 & 60.00 & 45.00 & 42.86 \\
\hline & & & (8) & (7) & (15) & (5) & (9) & (9) & (6) \\
\hline & 10 & & 47.05 & 21.42 & 65.00 & 42.86 & 53.00 & 30.00 & 50.00 \\
\hline & & & (8) & (3) & (13) & (6) & (8) & (6) & (7) \\
\hline \multirow[t]{3}{*}{ Average } & & & 47.05 & 35.71 & 65.00 & 35.71 & 73.33 & 38.33 & 50.00 \\
\hline & Over all & & 70.58 & 78.57 & 80.00 & 71.42 & 80.00 & 70.00 & 85.71 \\
\hline & populations & & (12) & (11) & (16) & (10) & (12) & (14) & (12) \\
\hline
\end{tabular}

tnb: Total number of bands revealed; number of polymorphic bands are given in parentheses.

Table III. Percentage of polymorphic loci $(P \%)$ in each population and each ecological group, Shannon's index and ratio of genetic diversity.

\begin{tabular}{|c|c|c|c|c|c|c|c|c|c|c|c|}
\hline & \multirow{2}{*}{$\begin{array}{l}\text { Bioclimate zones } \\
\text { Population code }\end{array}$} & \multicolumn{2}{|c|}{ Sh } & \multicolumn{3}{|c|}{ Usa } & \multicolumn{2}{|c|}{ Msa } & \multicolumn{3}{|c|}{ Lsa } \\
\hline & & 1 & 2 & 3 & 4 & 5 & 6 & 7 & 8 & 9 & 10 \\
\hline \multirow[t]{2}{*}{ Population } & $P \%$ & 59.65 & 56.14 & 57.89 & 62.28 & 64.91 & 61.40 & 51.75 & 50.00 & 51.75 & 44.74 \\
\hline & $\overline{\mathrm{H}}_{\mathrm{j}}^{\prime}$ & 0.593 & 0.576 & 0.597 & 0.667 & 0.687 & 0.627 & 0.517 & 0.458 & 0.502 & 0.469 \\
\hline \multirow[t]{2}{*}{ Ecological group } & $P \%$ & \multicolumn{2}{|c|}{57.15} & \multicolumn{3}{|c|}{61.51} & \multicolumn{2}{|c|}{56.44} & \multicolumn{3}{|c|}{49.30} \\
\hline & $\overline{\mathrm{H}}_{\mathrm{jg}}^{\prime}$ & \multicolumn{2}{|c|}{0.678} & \multicolumn{3}{|c|}{0.763} & \multicolumn{2}{|c|}{0.739} & \multicolumn{3}{|c|}{0.606} \\
\hline & 0.871 & & & \multirow{3}{*}{\multicolumn{3}{|c|}{$\begin{array}{c}\overline{\mathrm{H}}_{\mathrm{grp}}^{\prime} \\
\overline{\mathrm{H}}_{\mathrm{grp}}^{\prime} / \overline{\mathrm{H}}_{\mathrm{sp}}^{\prime} \\
\overline{\mathrm{G}}_{\mathrm{STg}}^{\prime}\end{array}$}} & \multicolumn{2}{|c|}{0.801} & & & \\
\hline$\overline{\mathrm{H}}_{\mathrm{pop}}^{\prime} / \overline{\mathrm{H}}_{\mathrm{sp}}^{\prime}$ & 0.653 & & & & & & \multicolumn{2}{|c|}{0.199} & & & \\
\hline$\overline{\mathrm{G}}_{\mathrm{ST}}^{\prime \prime}$ & 0.347 & & & & & & & & & & \\
\hline
\end{tabular}

Sh, Sub-humid; Usa, Upper semi-arid; Msa, Mean semi-arid; Lsa, Lower semi-arid. $\overline{\mathrm{H}}_{\mathrm{j}}^{\prime}, \overline{\mathrm{H}}_{\mathrm{pop}}^{\prime}, \overline{\mathrm{H}}_{\mathrm{sp}}^{\prime}, \overline{\mathrm{H}}_{\mathrm{pop}}^{\prime} / \overline{\mathrm{H}}_{\mathrm{sp}}^{\prime}$ and $\overline{\mathrm{G}}_{\mathrm{ST}}^{\prime}$ are the average per primer values of genetic diversity for each primer within each population $\left(\mathrm{H}^{\prime} \mathrm{j}\right)$, over all populations $\left(\mathrm{H}_{\mathrm{pop}}^{\prime}\right)$, whole sample $\left(\mathrm{H}_{\mathrm{sp}}^{\prime}\right)$ and their partition within- $\left(\mathrm{H}_{\mathrm{pop}}^{\prime} / \mathrm{H}_{\mathrm{sp}}^{\prime}\right)$ and between-populations $\left(\mathrm{G}_{S T}^{\prime}\right)$ components respectively, calculated for all primers. $\overline{\mathrm{H}}_{\mathrm{jg}}^{\prime}, \overline{\mathrm{H}}_{\mathrm{grp}}^{\prime}, \overline{\mathrm{H}}_{\mathrm{grp}}^{\prime} / \overline{\mathrm{H}}_{\mathrm{sp}}^{\prime}$ and $\overline{\mathrm{G}}_{\mathrm{STg}}^{\prime}$ are the average per primer values of genetic diversity for each primer within each ecological group $\left(\mathrm{H}_{\mathrm{j}}^{\prime}\right)$, over all groups $\left(\mathrm{H}_{\mathrm{grp}}^{\prime}\right)$, and their partition within- $\left(\mathrm{H}_{\mathrm{grp}}^{\prime} / \mathrm{H}_{\mathrm{p}}^{\prime}\right)$ and between-groups $\left(\mathrm{G}_{\mathrm{STg}}^{\prime}\right.$ respectively, calculated for all primers. 


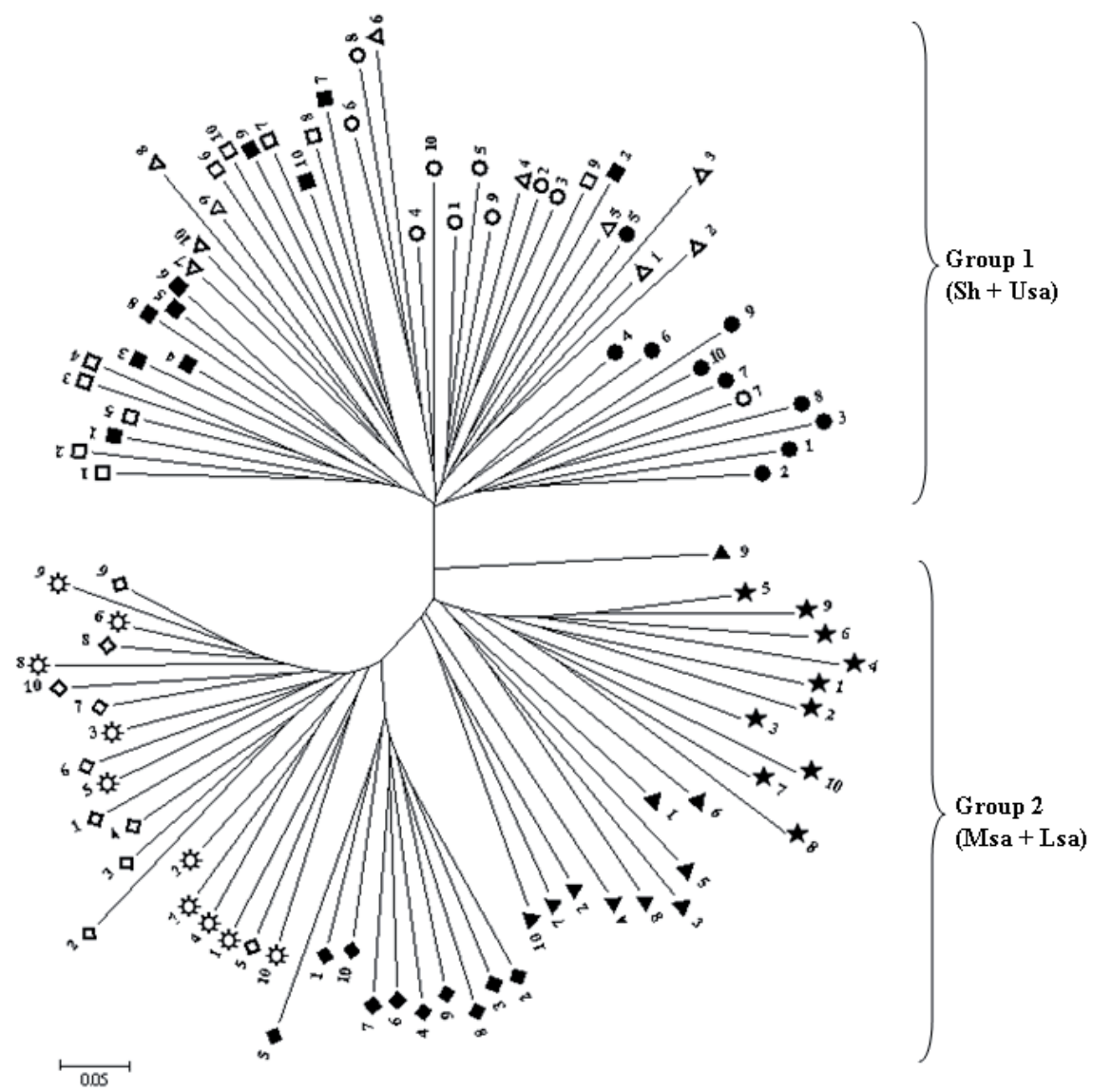

Figure 2. Neighbour-joining dendrogram generated from Jaccard similarity matrix for all individuals of Ceratonia siliqua analysed. Sh: subhumid; Usa: upper semi-arid; Msa: mean semi-arid; Lsa: lower semi-arid. Symbols indicate populations; individuals from the same population

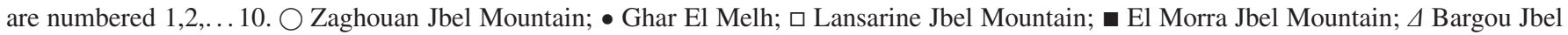
Mountain; $\mathbf{v}$ Ksar Lamsa; $\star$ Aïn Tounga; Jradou; $\diamond$ Khnis; $\diamond$ Oueslet Jbel Mountain.
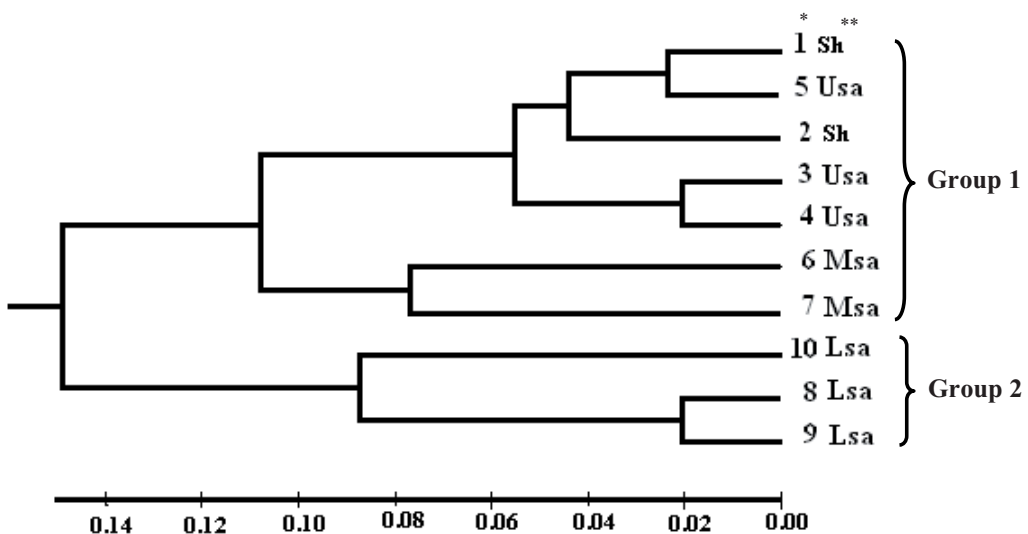

Figure 3. Dendrogram of the 10 populations of Carob studied based on the $\Phi_{\mathrm{ST}}$ values. * Population: 1 , Zaghouan Jbel Mountain; 2 , Ghar El Melh; 3, Lansarine Jbel Mountain; 4, El Morra Jbel Mountain; 5, Bargou Jbel Mountain; 6, Ksar Lamsa; 7, Aïn Tounga; 8, Jradou; 9 , Khnis; 10, Oueslet Jbel Mountain. ${ }^{* *}$ Bioclimate: Sh: Sub-humid; Usa: Upper semi-arid; Msa : Mean semi-arid; Lsa: Lower semi-arid. 
Table IV. Estimated gene flow (Nm) (above diagonal) and $\Phi_{\mathrm{ST}}$ values (below diagonal) between pairs of populations.

\begin{tabular}{lcccccccccc}
\hline Population & $\mathbf{1}$ & $\mathbf{2}$ & $\mathbf{3}$ & $\mathbf{4}$ & $\mathbf{5}$ & $\mathbf{6}$ & $\mathbf{7}$ & $\mathbf{8}$ & $\mathbf{9}$ & $\mathbf{1 0}$ \\
\hline $\mathbf{1}$ & & 2.245 & 1.640 & 3.222 & 5.024 & 0.950 & 0.815 & 0.465 & 0.458 & 0.442 \\
$\mathbf{2}$ & $0.100^{* * *}$ & & 1.213 & 1.986 & 3.083 & 1.001 & 0.641 & 0.449 & 0.488 & 0.447 \\
$\mathbf{3}$ & $0.132^{* * *}$ & $0.170^{* * *}$ & & 5.848 & 1.916 & 1.085 & 0.668 & 0.532 & 0.534 & 0.495 \\
$\mathbf{4}$ & $0.072^{* * *}$ & $0.111^{* * *}$ & $0.041^{* * *}$ & & 3.769 & 1.166 & 0.816 & 0.592 & 0.588 & 0.533 \\
$\mathbf{5}$ & $0.047^{n s}$ & $0.075^{* * *}$ & $0.115^{* * *}$ & $0.062^{* * *}$ & & 1.351 & 0.928 & 0.626 & 0.627 & 0.622 \\
$\mathbf{6}$ & $0.208^{* * *}$ & $0.199^{* * *}$ & $0.187^{* * *}$ & $0.176^{* * *}$ & $0.156^{* * *}$ & & 1.371 & 1.253 & 1.504 & 0.793 \\
$\mathbf{7}$ & $0.234^{* * *}$ & $0.280^{* * *}$ & $0.272^{* * *}$ & $0.234^{* * *}$ & $0.212^{* * *}$ & $0.154^{* * *}$ & & 0.601 & 0.676 & 0.624 \\
$\mathbf{8}$ & $0.349^{* * *}$ & $0.357^{* * *}$ & $0.319^{* * *}$ & $0.296^{* * *}$ & $0.285^{* * *}$ & $0.166^{* * *}$ & $0.293^{* * *}$ & & 5.862 \\
$\mathbf{9}$ & $0.353^{* * *}$ & $0.338^{* * *}$ & $0.318^{* * *}$ & $0.298^{* * *}$ & $0.285^{* * *}$ & $0.142^{* * *}$ & $0.270^{* * *}$ & $0.040^{* * *}$ & \\
$\mathbf{1 0}$ & $0.361^{* * *}$ & $0.358^{* * *}$ & $0.335^{* * *}$ & $0.319^{* * *}$ & $0.286^{* * *}$ & $0.239^{* * *}$ & $0.285^{* * *}$ & $0.189^{* * *}$ & $0.160^{* * *}$ & 1.313 \\
\hline
\end{tabular}

ns, Not significant; ${ }^{* * *}$, highly significant at $P<0.001$ after 1000 permutations. 1, Zaghouan Jbel Mountain; 2, Ghar El Melh; 3 , Lansarine Jbel Mountain; 4, El Morra Jbel Mountain; 5, Bargou Jbel Mountain ; 6, Ksar Lamsa; 7, Aïn Tounga ; 8, Jradou; 9, Khnis; 10, Oueslet Jbel Mountain.

Table V. Nested analysis of molecular variance (AMOVA) of random amplified polymorphic DNA for all individuals sampled from 10 populations belonging to 4 ecological groups.

\begin{tabular}{|c|c|c|c|c|c|}
\hline Source of variation & df & MSD & Variance & Total variance $(\%)$ & $\Phi$-statistics \\
\hline \multicolumn{6}{|l|}{ Population } \\
\hline Among populations & 9 & 0.822 & 0.061 & $22.89^{* * *}$ & $\Phi_{\mathrm{ST}}=0.250^{* * *}$ \\
\hline Within population & 90 & 0.207 & 0.207 & $77.11^{* * *}$ & \\
\hline Total & 99 & & & & \\
\hline \multicolumn{6}{|l|}{ Ecological group } \\
\hline Among groups & 3 & 1.533 & 0.043 & $15.66^{* * *}$ & $\Phi_{\mathrm{CT}}=0.157^{* * *}$ \\
\hline Among populations Within group 6 & 0.466 & 0.02 & $9.38^{* * *}$ & $\Phi_{\mathrm{SC}}=0.111^{* * *}$ & \\
\hline Within population & 90 & 0.207 & 0.207 & $74.96^{* * *}$ & \\
\hline Total & 99 & & & & \\
\hline
\end{tabular}

df, Degree of freedom; SSD, sum of squared deviation; MSD, mean squared deviation. ${ }^{* * *}$ Significant at $P<0.001$ after 1000 permutations.

$P<0.05$ after 999 permutations) were significant. The correlation between $\Phi_{\mathrm{ST}}$ and site altitudes matrices was not significant $\left(r^{2}=0.002, P>0.05\right.$ after 999 permutations).

The dendrogram generated from pairwise $\Phi_{\mathrm{ST}}$ matrix among populations showed two major groups (Fig. 3). The first one which could be subdivided into two subclusters includes populations 1, 2, 3, 4 and 5 from the sub-humid and upper semi-arid (subcluster 1) and populations 6 and 7 from the mean semi-arid bioclimate (subcluster 2). The second group includes the three populations 8,9 and 10 belonging to the lower semi-arid. The divergence between populations based on RAPDs was similar to that based on isozymes (Afif et al., 2006).

The analysis of the molecular variance (AMOVA) attributed $77.11 \%(P<0.001)$ of the total genetic diversity to differences within population, only $22.89 \%$ was attributable to the population divergence (Tab. V). The $\Phi_{\mathrm{ST}}$ among all populations was $0.250(P<0.001)$ indicating a high differentiation among them. The level of AMOVA, which considered the ten populations as four groups (according to bioclimate) indicated that the majority of variation $(74.96 \%, P<0.001)$ resided within population. Variation observed between populations belonging to the same bioclimatic zone was lower $(9.38 \% ; P<0.001)$ than that among the three ecological groups $(15.66 \%$; $P<$
$0.001)$ and both showed a high differentiation $\left(\Phi_{\mathrm{CT}}=0.157\right.$; $\Phi_{\mathrm{SC}}=0.11 ; P<0.001$, respectively) $($ Tab. V).

\section{DISCUSSION}

Natural Tunisian carob populations maintain a high genetic diversity as revealed by RAPDs estimates. The level of variation was higher than that reported for Lebanon semi natural carob populations (Talhouk et al., 2005). It could be explained by the predominantly outbreeding mating system. The species is gynodicious (male and female), rarely hermaphrodite (Battle and Tous, 1997; Haselberg 1986; Tucker, 1992) and entomophilous (pollination by flies). Outcrossing species showed higher variation within than among populations (Nybom and Bartish, 2000). The gene flow via seed or pollen migration between adjacent populations might be favoured by the continuous distribution area of the species before population fragmentation.

The genetic diversity based on RAPDs was relatively higher than that revealed by isozymes for the same populations (Afif et al., 2006). These results are in agreement with those reported for forest trees comparing molecular and isozymic data (Aagaard et al., 1998; Bucci et al., 1997; Gómez et al., 2001; 
Messaoud et al., 2007; Yildiray et al., 2007). RAPDs are less responsive to selection and are able to detect high variation both in coding and non-coding regions of the genome (Allnutt et al., 2003; Nybom and Bartish, 2000; Wu et al., 1999).

The range of variation between populations was large. Populations from Zaghouan Jbel Mountain (1) and Bargou Jbel Mountain (5) with a large size and more continuous distribution area (both located in Tunisian Dorsal Mountain) showed the highest diversity. Besides, these populations have shown high variation in their pod and seed sizes, number of seeds per pod and gum and sugar yields (Tous et al., 2006). Populations from Jradou, Knis and Oueslet Jbel Mountain, with a little size and scattered individuals, were less heterogeneous.

All the estimates of genetic differentiation $\left(\mathrm{G}_{\mathrm{ST}}^{\prime}=34.7\right.$ $\%$ and $\Phi_{\mathrm{ST}}=0.250$ ) indicate that population genetic structure was high in comparison with wind pollinated forest trees (Fournier et al., 2006; Godt and Hamrick, 2001; Pvingila et al., 2005). The genetic structure of plant populations reflects the interactions among different factors, including the long-term evolutionary history of the species, genetic drift, mating system, gene flow and selection (Burgarella et al., 2007; Schaal et al., 1998). Geographically disjunct populations showed higher genetic structure than populations with more continuous distributions (Hamrick and Godt 1996; Premoli et al., 2001). The fragmentation of carob populations associated probably to a limited movement of pollinators and seed dispersal are the main factors affecting gene flow and differentiation among population. No intense study on seed dispersal distance was reported in carob tree.

The population structure is significantly correlated to geographic distances, and it is in accordance with bioclimate as defined by Emberger (1966). However, isolation by distance did not sufficiently explain this differentiation. Populations from Zaghouan and Oueslet Jbel Mountains, distant by $75 \mathrm{~km}$ and belonging to different bioclimates, showed high level of dissimilarity and did not clustered together. Thus, the genetic structure also could be derived from adaptive RAPD differentiation in response to ecological factors (i.e. temperature, rainfall) (Kölliker et al., 1998; Nevo and Beiles, 1989).

The differentiation among ecological groups $\left(\Phi_{\mathrm{CT}}=0.157\right)$ and among the populations from the same group $\left(\Phi_{\mathrm{SC}}=\right.$ 0.111 ) is moderate and significant. The demand for Ceratonia siliqua $\mathrm{L}$. is in increasing for its use in industrial fields and in the restoration of degraded arid zones. However, natural populations which provide the bulk materiel are decreasing in number and size as a result of diverse anthropic pressures. Limiting the species habitat destruction and coal mining and to the selection of cultivars with traits of interests to targets breeders constitute an effective strategy to preserve populations. Improvement work carried out since 1950 has led to a selection (from natural populations) of Ceratonia siliqua cv. Sfax (high production of pods with high sugar and gum contents, excellent flavour, etc.). This cultivar in Tunisia has been eradicated in most areas (several orchards persist in Souassy and Enfidha regions. It has been introduced in the USA (California), Australia and Spain and is considered as the most productive cultivar (Battle and Tous, 1997; CrossaRaynaud, 1960).
The analysis of RAPD markers provides information that could be a benefit in conservation and improvement strategies. The significant variation within and among Tunisian carob populations suggests that populations constitute a valuable germplasm to conceive suitable conservation and genetic improvement programs. However, no study on the relationship between RAPDs considered as neutral (or nearly neutral) and adaptive markers has been reported. The assessment of the correlation between the tow sets of traits might help to better knowledge of adaptive potential and for future use of populations (Hansson and Richardson, 2005; Hedrick, 2001; van Tienderen, 2002).

The level of variation differed according to population and bioclimate. Population of Bargou and Zaghouan Jbel Mountains, harbouring the high diversity level (both by RAPDs and isozymes), firstly should be more preserved. The significant differentiation among ecological groups suggests that in situ conservation should be made appropriately according to bioclimate and site disturbance level.

The genetic variation was due: $77.11 \%$ within population while $28.29 \%$ was distributed among populations (or ecological groups $15.66 \%$ ), thus, ex situ conservation should be based on the collect of a maximum of individuals within populations and their multiplication via grafting in multilocal parks.

Further genetic diversity analyses combining molecular and adaptive traits are needed to more intense information of population genetic structure and to dictate appropriate decision associating conservation and management strategies of the species.

Acknowledgements: The authors thank the Tunisian Ministry of Scientific Research and Technology and the National Institute of Applied Science and Technology for their financial support (Research grant 99/UR/09-10).

\section{REFERENCES}

Aagaard J.E., Krutovskii K.V., and Strauss S.H., 1998. RAPDs and allozymes exhibit similar levels of diversity and differentiation among populations and races of Douglas-fir. Heredity 81: 69-78.

Afif M., Ben Fadhel N., Koudja M.L., and Boussaid M., 2006. Genetic Diversity in Tunisian Carob (Ceratonia siliqua L.) Natural Populations. Genet. Res. Crop Evol. 53: 1501-1511.

Albanell E., Caja G., and Plaixats J., 1991. Characteristics of Spanish carob pods and nutritive value of carob kibbles. CIHEAM Option Médiremanéenes 16: 135-136.

Albanell E., Caja G., and Plaixats J., 1996. Characterization of carob fruits (Ceratonia siliqua L.), cultivated in Spain for agro industrial use. Int. Tree Crops J. 9: 1-9.

Allnutt T.R., Newton A.C., Premoli A., and Lara A., 2003. Genetic variation in the threatened South American conifer Pilgerodendron uviferum (Cupressaceae), detected using RAPD markers. Biol. Conserv. 114: 245-253.

Bartlett M.S., 1937. Some examples of statistical methods of research on agriculture and applied biology. J. Roy. Stat. Soc., Supp. 4: 137-170.

Battle I., 1997. Current situation and possibilities of development of the carob tree (Ceratonia siliqua L.) in the Mediterranean region. Unpublished FAO Report. Rome, Italy. 
Battle I. and Tous J., 1997. Carob tree. Ceratonia siliqua, L. Promoting the conservation and use of underutilized and neglected crops. 17. Institute of Plant Genetics and Crop Plant Research, Gatersleben/International Plant Genetic Resources Institute (eds), Rome, Italy, $92 \mathrm{p}$.

Besse P., Da Silva D., Bory S., Grisoni M., Le Bellec F. and Duval M.F., 2004. RAPD genetic diversity in cultivated vanilla: Vanilla planifolia, and relationships with $V$. tahitensis and V. pompona. Plant Sci. 167: 379-385.

Boussaïd M., Ben Fadhel N., Chemli R. and Ben M'hamed M., 1998. Structure of vegetation in Northern and Central Tunisia and protective measures. CIHEAM Options Méditerranéennes 38: 295-302.

Bucci G., Kubisiak T.L., Nance W.L., and Menozzi P., 1997. A population consensus partial linkage map of Picea abies Karst. based on RAPD markers. Theor. Appl. Genet. 95: 643-654.

Burgarella C., Navascués M., Soto Á., Lora Á., and Fici S., 2007. Narrow genetic base in forest restoration with holm oak (Quercus ilex L.) in Sicily. Ann. For. Sci. 64: 757-763.

Calixto F.S. and Canellas J., 1982. Components of nutritional interest in carob pods (Ceratonia siliqua). J. Sci. Food Agric. 33: 1319-1323.

Christoph R., Anja A., and Markus R., 2005. Molecular variation within and between ten populations of Primula farinosa (Primulaceae) along an altitudinal gradient in the northern Alps. Basic Appl. Ecol. 6: $35-45$.

Correia P.J. and Martin-Louçào M.A., 2005. The use of macronutrients and water in marginal Mediterranean areas: the case of carob-tree. Field Crops Res. 91: 1-6.

Corsi L., Avallone R., Cosenza F., Farina F., Baraldi C., and Baraldi M., 2002. Antiproliferative effects of Ceratonia siliqua L. on mouse hepatocellular carcinoma cell line. Fitoterapia 73: 674-684.

Crossa-Raynaud P., 1960. Problèmes d'arboriculture fruitière en Tunisie. Ann. Inst. Nat. Rech. Agro. Tunisie, 33: 79-83.

Emberger L., 1966. Une classification biogéographique des climats. Recherches et Travaux des Laboratoires de Géologie, Botanique et Zoologie, Faculté des Sciences Montpellier (France) 7: 1-43.

Excoffier L., Smouse P.E., and Quattro J.M., 1992. Analysis of molecular variance inferred from metric distances among DNA haplotypes: application to human mitochondrial DNA restriction data. Genetics 131: 479-491.

Fischer M., Husi R., Prati D., Peintinger M., van Kleunen M., and Schmid B., 2000. RAPD variation among and within small and large populations of the rare clonal plant Ranunculus reptans (Ranunculaceae). Am. J. Bot. 87: 1128-1137.

Fournier N., Rigling A., Dobbertin M., and Gugerli F., 2006. Faible différenciation génétique, à partir d'amplification aléatoire d'ADN polymorphe (RAPD), entre les types de pin sylvestre (Pinus sylvestris L.) d'altitude et de plaine dans les Alpes à climat continental. Ann. For. Sci. 63: 431-439.

Godt M.J.W., Hamrick J.L., Edwards-Burke M.A., and Williams J.H., 2001. Comparisons of genetic diversity in white spruce (Picea glauca) and jack pine (Pinus banksiana) seed orchards with natural populations. Can. J. For. Res. 31: 943-949.

Gómez A., Alia R., and Bueno M.A., 2001. Genetic diversity of Pinus halepensis Mill. Populations detected by RAPD loci. Ann. For. Sci. 58: $869-875$.

Gower J.C. and Legendre P., 1986. Metric and Euclidean properties of dissimilarity coefficients. J. Classif. 31: 5-48.

Hamrick J.L. and Godt M.J.W., 1996. Effects of life history traits on genetic diversity in plant species. Philos. Trans. Roy. Soc. London, Series B 351: 1291-1298.
Hansson B. and Richardson D.S., 2005. Genetic variation in two endangered Acrocephalus species compared to a widespread congener: estimates based on functional and random loci. Cambridge University Press 8: 83-90.

Haselberg C.V., 1986. Flowering characteristics of male and female carob flowers, $1^{\circ}$ Encontro Linhas Investigação de Alfarroba, Oeiras, Portugal, pp. 45-56.

Hedrick P.W., 2001. Conservation genetics: where are we now? Trends Ecol. Evol. 16: 629-636.

Khair M., El-Shatnawi J., and Ereifej K.I., 2001. Chemical composition and livestock ingestion of carob (Ceratonia siliqua L.) seeds. J. Range Manage. 54: 669-673.

Kölliker R., Stadelmann F.J., Reidy B., and Nösberger J., 1998. Fertilization and defoliation frequency affect genetic diversity of Festuca pratensis Huds. In permanent grasslands. Mol. Ecol. 7: $1557-1567$.

Kovach W.L., 1999. A Multivariate Statistical Package for Windows, ver 3.1., Kovach Computing Services, Pentraeth, UK.

Kumar S., Tamura K., Jakobsen I.B., and Nei M., 2001. MEGA2: Molecular evolutionary genetics analysis software. Bioinformatics 17: 1244-1245.

Le Houerou H.N. and Le Floc'h E., 1995. La végétation de la Tunisie centrale et méridionale : Flore et dynamique à long terme de la végétation tunisienne, In: Essai de synthèse sur la végétation et la phytoécologie tunisiennes. Eds. I.O.R. Tunisie, pp. 355-388.

Lee S.W., Ledig F.T., and Johnson D.R., 2002. Genetic variation at allozyme and RAPD markers in Pinus longaeva (Pinaceae) of the White Mountains, California. Am. J. Bot. 89: 566-577.

Lodhi M.A., Ye G-N., Weeden N.F., and Reisch B.I., 1994. A simple and efficient method for DNA extraction from grapevine cultivars and Vitis species. Plant Mol. Biol. Report. 12: 6-13.

Mantel N., 1967. The detection of disease clustering and a generalized regression approach. Cancer Res. 27: 209-220.

Mariette S., Balsemin E., Stoeckel S., Tavaud M., Le Bouler H., Santi F., and Verger M., 2007. Parental participation in progeny and effective population sizes in experimental seed orchards of wild cherry Prunus avium L. (Batsch). Ann. For. Sci. 64: 533-539.

Messaoud C., Afif M., Boulila A., Rejeb M.N., and Boussaid M., 2007. Genetic variation of Tunisian Myrtus communis L. (Myrtaceae) populations assessed by isozymes and RAPDs. Ann. For. Sci. 64: 845853.

Miller M.P., 1997. Tools for population genetic analyses (TFPGA) 1.3: A Windows program for the analysis of allozyme and molecular population genetic data, Computer software distributed by author.

Mitrakos K., 1968. The carob (Ceratonia siliqua L.). Report to Tate and Lyle, Reading, $30 \mathrm{p}$.

Nevo E. and Beiles A., 1989. Genetic diversity of wild emmer wheat in Israel and Turkey. Structure, evolution and application in breeding. Theor. Appe. Genet. 77: 421-455.

Nybom H. and Bartish I.V., 2000. Effects of life history traits and sampling strategies on genetic diversity estimates obtained with RAPD markers in plants, Perspect. in Plant Ecol. Evol. Syst. 3: 93-114.

Premoli A.C., Souto C.P., Allnutt T.R., and Newton A.C., 2001. Effects of population disjunction on isozyme variation in the widespread Pilgerodendron uviferum. Heredity 87: 337-343.

Rejeb M.N., 1989. Mécanismes physiologiques d'adaptation à la sécheresse du Caroubier. Rv. Res. Amélior. Prod. Milieu Aride I: 47-55.

Roukas T., 1994. Continuous ethanol productions from carob pod extract by immobilized Saccharomyces cerevisiae in a packed bed reactor. J. Chem. Technol. Biotechnol. 59: 387-393. 
Saitou N. and Nei M., 1987. The neighbour-joining method: a new method for reconstructing phylogenetic trees. Mol. Biol. Evol. 4: $406-425$.

Schaal B.A., Hayworth D.A., Olsen K.M., Rauscher J.T., and Smith W.A., 1998. Phylogeographic studies in plants: problems and prospects. Mol. Ecol. 7: 465-474.

Stewart C.N.J. and Excoffier L., 1996. Assessing population genetic structure and variability with RAPD data: application to Vaccinium macrocarpon (American cranberry). J. Evol. Biol. 9: 153-171.

Sudupak M.A., Akkaya M.S., and Kence A., 2002. Analysis of genetic relationships among perennial and annual Cicer species growing in Turkey using RAPD markers. Theor. Appl. Genet. 105: 1220-1228.

Tvingila D., Verbylaitë R., Baliuckas V., Pliûra A., and Kuusienë S., 2005. Genetic diversity (RAPD) in natural Lithuanian populations of common ash (Fraxinus excelsior L.). Biologija 3: 46-53.

Talhouk S.N., Van Breugel P., Zurayk R., Al-Khatib A., Estephan J., Ghalayini A., Debian N., and Lychaa D., 2005. Status and prospects for the conservation of remnant semi-natural carob Ceratonia siliqua L. populations in Lebanon. For. Ecol. Manage. 206: 49-59.

Tous J., Olarte C., Truco M.J. and Arús P., 1992. Isozyme polymorphisms in carob cultivars. Hort. Sci. 27: 257-258.
Tous J., Rovira M., Romero A., Afif M., Khouja M.L., Naghmouchi S., and Boussaid M., 2006. Carob tree germplasm in Tunisia. FAOCIHEAM, Nucis Newsletter 13: 55-59.

Tucker S.C., 1992. The developmental basis for sexual expression in Ceratonia siliqua (Leguminosae: Caesalpinioideae: Cassieae). Am. J. Bot. 79: 318-327.

Van Tienderen P.H., de Haan A.A., van der Linden C.G., and Vosman B., 2002. Biodiversity assessment using markers for ecologically important traits. Trends Ecol. Evol. 17: 577-582.

Williams J.G.K., Kubelik A.R., Rafalski K.J., and Tingey S.V., 1990. DNA polymorphisms amplified by arbitrary primers are useful as genetic markers. Nucl. Acids Res. 18: 6531-6535.

Wright S., 1951. The genetical structure of populations. Ann. Eugenics 15: 323-354.

Wu J., Krutovskii K.V., and Strauss S.H., 1999. Nuclear DNA diversity, population differentiation, and phylogenetic relationships in the California closed-cone pines based on RAPD and allozyme markers. Genome 42: 893-908.

Yildiray L., Zeki K., Fikret I., Rumi S., Irfan , and Sertac O., 2007. The impact of over-exploitation on the genetic structure of Turkish red pine (Pinus brutia Ten.) populations determined by RAPD markers. Silva fenn. 41: 211-220. 


\section{Online Material}


ADDENDA
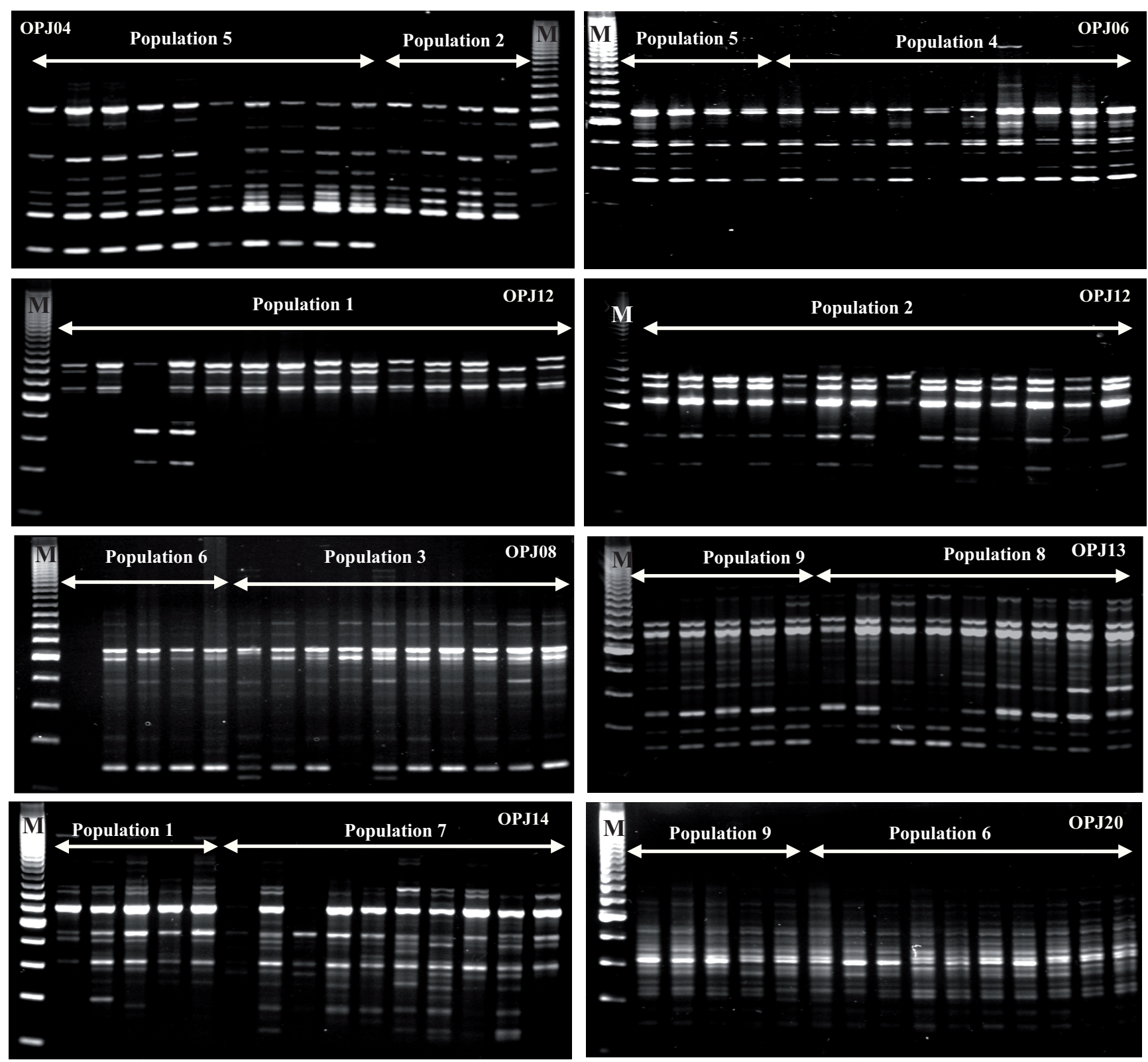

Examples of DNA profiles revealed by the 7 analyzed primers (OPJ04, OPJ06, OPJ12, OPJ08, OPJ13, OPJ14 and OPJ20) in some populations.

M: Size Marker. 


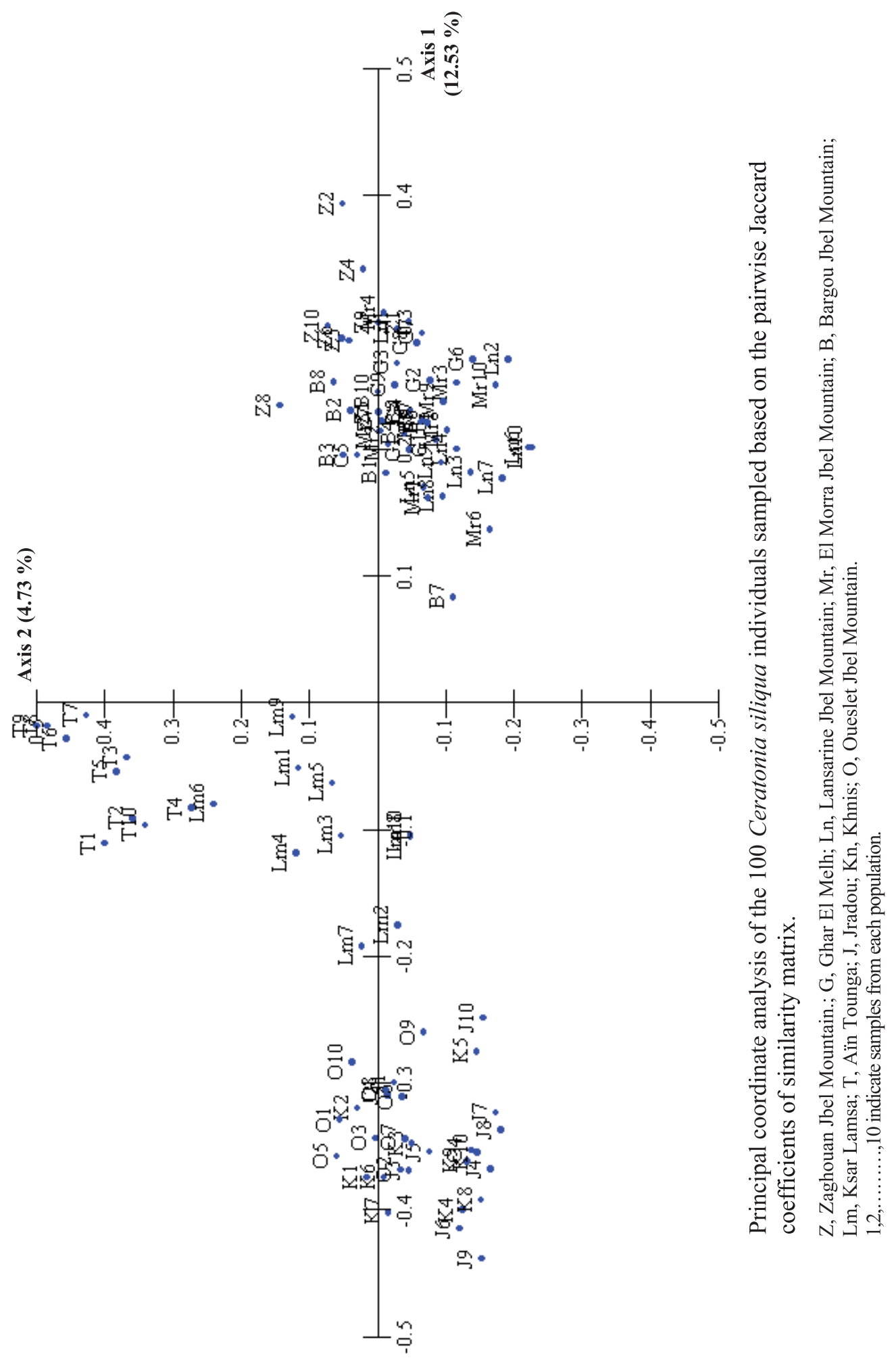

